\title{
Making the Violation Fit the Remedy: The Intent Standard and Equal Protection Law
}

The 1976 decision of the Supreme Court in Washington v. Davis ${ }^{1}$ imposed a new burden upon equal protection plaintiffs: proof of invidious intent or purpose. ${ }^{2}$ This Note argues that the development of the intent standard since Davis is best understood as a stratagem to limit the scope of relief available to the equal protection litigant. Focusing on the Court's decision in City of Mobile v. Bolden, ${ }^{3}$ this Note draws out the underlying hostility to broad remedial orders in equal protection cases, from $D$ avis to the present, and demonstrates how that hostility has colored the development of the intent doctrine.

\section{The Development of the Intent Standard}

The Warren Court developed two-tier equal protection scrutiny primarily in response to overt discriminatory practices whose purpose and effect were identical and unmistakable. The question of intent emerged in equal protection analysis only when the focus of litigation shifted to the discriminatory impact of practices not facially discriminatory. Not until Washington v. Davis was it suggested that the intent to discriminate was a necessary part of an equal protection violation.

\section{A. Two-Tier Scrutiny}

Prior to Davis, equal protection analysis proceeded primarily along two tiers of review. State action infringing upon fundamental rights ${ }^{6}$ or em-

1. 426 U.S. 229 (1976).

2. This Note uses the terms "intent," "purpose," and "motive" interchangeably. While a great deal has been written about the nuances of the different meanings of each, see A. BICKEL, THE LEAST DANGEROUS BRANCH 209 (1962), the Court has failed to give significance to these differences, see Brest, Palmer v. Thompson: An Approach to the Problem of Unconstitutional Legislative Motive, 1971 SUP. CT. REV. 95, 104 n.55; Clark, Legislative Motivation and Fundamental Rights in Constitutional Law, 15 SAN DIEGO L. REV. 953, 955-62 (1978); Eisenberg, Disproportionate Impact and Illicit Motive: Theories of Constitutional Adjudication, 52 N.Y.U. L. REV. 36, 106 n.321 (1977); Ely, Legislative and Administrative Motivation in Constitutional Law, 79 YALE L.J. 1205, 1217-21 (1970).

3. 446 U.S. 55 (1980) (plurality opinion).

4. "The Warren Court embraced a rigid two-tier attitude. Some situations evoked the aggressive 'new' equal protection, with scrutiny that was 'strict' in theory and fatal in fact; in other contexts, the deferential 'old' equal protection reigned with minimal scrutiny in theory and virtually none in fact." Gunther, The Supreme Court, 1971 Term-Foreword: In Search of Evolving Doctrine on a Changing Court: $A$ Model for a Newer Equal Protection, 86 HARv. L. Rev. 1, 8 (1972).

5. See, e.g., Roe v. Wade, 410 U.S. 113 (1973) (right of protection of activities of uniquely private 
ploying a suspect classification ${ }^{6}$ was subject to strict scrutiny. Strict scrutiny created a presumption of unconstitutionality, which could be rebutted only by establishing both a compelling state interest and a tight fit between the means chosen and the state objective. ${ }^{7} \mathrm{~A}$ challenged state action not falling within one of these categories needed only to bear a rational relation to the articulated state purpose. ${ }^{8}$

Strict scrutiny may be said to have inferred motive; once invoked, courts presumed illicit purpose and imposed a high burden of proof upon the state's rebuttal. ${ }^{\circ}$ But the exact relationship between intent and an equal protection violation was never clearly established. ${ }^{10}$ As pointed out by

nature); Bullock v. Carter, 405 U.S. 134 (1972) (right to vote); Shapiro v. Thompson, 394 U.S. 618 (1969) (right of interstate travel); Williams v. Rhodes, 393 U.S. 23 (1968) (rights guaranteed by the First Amendment); Douglas v. California, 372 U.S. 353 (1963) (right to an adequate criminal defense); Griffin v. Illinois, 351 U.S. 12 (1956) (same); Skinner v. Oklahoma ex rel. Williamson, 316 U.S. 535 (1942) (right to procreate).

The nearly automatic invalidation of statutes affecting fundamental rights made the Court hesitant to expand the category of rights considered fundamental. Massachusetts Bd. of Retirement v. Murgia, 427 U.S. 307, 319 (1976) (Marshall, J., dissenting); cf. id. at 307 (majority opinion) (right to work not a fundamental right); San Antonio School Dist. v. Rodriguez, 411 U.S. 1 (1973) (education not a fundamental right).

6. The concept of suspect classification originated in Korematsu v. United States, 323 U.S. 214, 216 (1944). While primarily applied to race, see McLaughlin v. Florida, 379 U.S. 184 (1964), it has also been held to include ancestry, see Oyama v. California, 332 U.S. 633 (1948), and alienage, see Graham v. Richardson, 403 U.S. 365 (1971). But cf. Frontiero v. Richardson, 411 U.S. 677 (1973) (refusal to treat sex as a suspect classification).

7. See Kramer v. Union School Dist. No. 15, 395 U.S. 621 (1968) (property-based qualifications for voting struck down under strict scrutiny).

8. See, e.g., Massachusetts Bd. of Retirement v. Murgia, 427 U.S. 307, 314 (1976) (legitimate classifications valid unless they bear no rational relation to state's objectives); San Antonio School Dist. v. Rodriguez, 411 U.S. 1, 17 (1973) (classifications must rationally further some legitimate, articulated state purpose).

Because of the sharp contrast between the two levels of scrutiny, the Court came under pressure to adopt, and ultimately adopted, intermediate tiers. See, e.g., Craig v. Boren, 429 U.S. 190, 211 (1976) (Powell, J., concurring) (gender based classification requires "a fair and substantial relation to the object of the legislation"); Reed v. Reed, 404 U.S. 71, 76-77 (1971) (same).

9. Professor Ely notes that "the doctrine of 'suspect classifications,' though not generally so understood, turns out on analysis to function as a handmaiden of motivation analysis." J. ELY, DEMOCRACY AND DISTRUST 145 (1980). He views suspectness as a way in which the Court has extended the inquiry to determine "whether the initial suspicions aroused by the classification are well founded or rather on fuller exploration can be allayed." Id. at 147; see Simon, Racially Prejudiced Governmental Actions: A Motivation Theory of the Constitutional Ban Against Racial Discrimination, 15 SAN DIEGO L. REV. 1041, 1069 (1978).

The Court's failure to articulate the exact source of the violation reflects uncertainty over the precise substantive rights afforded by the Constitution. Part of this uncertainty stems from the language of the Fourteenth Amendment and the ambiguity of the value of equality that it constitutionalizes. See Fiss, Groups and the Equal Protection Clause, 5 PHIL. \& PUB. AFF. 107, 108 (1976). The Court has wavered between a concept of equal treatment, which connotes equality in the process of allocating social rewards, and equal status, which points to equality of results. See Comment, Proof of Racially Discriminatory Purpose Under the Equal Protection Clause: Washington v. Davis, Arlington Heights, Mt. Healthy and Williamsburgh, 12 HARV. C.R.-C.L. L. REV. 725, 727-28 (1977).

10. See generally Eisenberg, supra note 2 (criticizing narrow focus on legitimacy of governmental action underlying intent doctrine); Karst, The Supreme Court, 1976 Term-Foreword: Equal Citizenship Under the Fourteenth Amendment, 91 HARV. L. REV. 1 (1977) (advocating "equal citizenship" doctrine to escape doctrinal confusion); Tussman \& tenBroek, The Equal Protection of the Laws, 37 CALIF. L. REV. 341, 342-44 (1949) (seminal formulation of need for government to treat 
Justice Marshall, the Warren Court's decisions were compatible with three divergent propositions: (i) that purpose alone was the test of constitutionality; (ii) that effects alone were the test; and (iii) that some combination of purpose and effects defined constitutionality. ${ }^{11}$

The issues before the Warren Court did not require a clear articulation of the relationship between intent and an equal protection violation. In cases that involved the dismantling of state-imposed segregation, such as Brown v. Board of Education, ${ }^{12}$ discriminatory purpose was expressed on the face of the statutes or ordinances and was inseparable from the ensuing effects. When courts were later confronted with secondary forms of discrimination-facially neutral practices adopted to perpetuate de jure segregation and often taken to circumvent judicial desegregation orders ${ }^{13}$-the relation between purpose and effects was no longer selfevident.

Not only was the relationship between intent and liability uncertain, it was uncertain whether evidence of intent was even admissible to establish a violation. The Court's decisions in United States v. O'Brien ${ }^{14}$ and Palmer v. Thompson ${ }^{15}$ rejected any direct inquiry into motive ${ }^{\mathbf{1 6}}$ and prompted the seminal articles by Professors Ely ${ }^{17}$ and Brest ${ }^{18}$ arguing for the centrality of legislative motive in establishing a constitutional violation. Intent was resurrected by Justice Brennan in Keyes v. School District No. $1{ }^{19}$ which presented the Court with the first challenge to school segregation in a jurisdiction without a history of de jure race separation. Justice Brennan's opinion defined purposeful segregation as the equivalent of de jure segregation, ${ }^{20}$ thus bringing it within the analytic framework applica-

similarly those similarly situated under equal protection doctrine).

11. Beer v. United States, 425 U.S. 130, 148 n.4 (1976) (Marshall, J., dissenting). See generally Eisenberg, supra note 2, at 39 (confusion over roles of impact and motive of disastrous proportions); Ely, supra note 2, at 1207 (confusion over role of motive); Samford, Toward a Constitutional Definition of Racial Discrimination, 25 EMORY L.J. 509 (1976) (same).

12. 347 U.S. 483 (1954).

13. See, e.g., Palmer v. Thompson, 403 U.S. 217 (1971) (swimming pools of Jackson, Miss., closed in response to desegregation order); Griffin v. County School Bd., 377 U.S. 218 (1964) (school system shut down to escape compliance with court desegregation order).

14. 391 U.S. 367 (1968).

15. 403 U.S. 217 (1971).

16. The Court in O'Brien asserted: "The decisions of this Court from the beginning lend no support whatever to the assertion that the judiciary may restrain the exercise of lawful power on the assumption that a wrongful purpose or motive has caused the power to be exercised." " 391 U.S. at 383 (quoting McCray v. United States, 195 U.S. 27, 56 (1904)). In Palmer, the Court declared that it had never "held that a legislative act may violate equal protection solely because of the motivations of the men who voted for it." 403 U.S. at 224.

17. Ely, supra note 2 .

18. Brest, supra note 2.

19. 413 U.S. 189 (1973). Professor Brest saw in Keyes an acknowledgement of the need to expand the evidentiary base for equal protection claims. Brest, The Supreme Court, 1975 Term-Foreword: In Defense of the Antidiscrimination Principle, 90 HARV. L. REV. 1, 28 (1976).

20. 413 U.S. at 208. 
ble to suspect classifications. While Keyes allowed proof of invidious intent to suffice in establishing a claim of unconstitutional discrimination, it did not hold that intent was a necessary criterion for liability. ${ }^{21}$

\section{B. The Articulation of the Intent Standard}

The intent test took on a life of its own three years later in Washington v. Davis, ${ }^{22}$ which effectively turned Keyes on its head and fundamentally altered the presumptions of prior equal protection doctrine. Prior to $\mathrm{Da}$ vis, the Court had not addressed the question of whether the discriminatory impact of state action was sufficient to establish liability, ${ }^{23}$ but lower federal courts had treated state actions with disproportionate racial impact as creating a "suspect (racial) classification" and therefore subject to a test approximating strict scrutiny. ${ }^{24}$ Davis rejected that approach, holding that strict scrutiny would be applied only where a discriminatory impact on a suspect class was accompanied by a showing of invidious purpose; ${ }^{25}$ such purpose would not be presumed simply because the disadvantaged group was a suspect class. $^{26}$

The full significance of Davis depended crucially on what effects, if

21. See Annual Conference of Second Judicial Circuit, 74 F.R.D. 215, 277 (1976) (comments of Prof. Owen Fiss) (Keyes held intent sufficient but not necessary); Note, Reading the Mind of the School Board: Segregative Intent and the De Facto/De Jure Distinction, 86 YALE L.J. 317, 349-52 (1976) (same). The Court held that where intent established de jure segregation it was sufficient to impose a duty on school authorities to effectuate a transition to a racially nondiscriminatory system. Keyes, 413 U.S. at 208. The Court's opinion did not address what, if anything, would satisfy a de facto challenge to segregation.

22. 426 U.S. 229 (1976). Prior to Davis, the extent to which intent was needed to establish liability was uncertain; afterwards it was uncertain to what degree the effects of discrimination would be considered probative of a constitutional violation. "Disproportionate impact is not irrelevant, but it is not the sole touchstone of an invidious racial discrimination forbidden by the Constitution." Id. at 242.

23. In Wright v. Council of Emporia, 407 U.S. 451 (1972), the Court upheld an effects test to weigh the constitutionality of action taken to promote or thwart desegregation. "[W]e have focused upon the effect-not the purpose or motivation-of a school board's action in determining whether it is a permissible method of dismantling a dual system. The existence of a permissible purpose cannot sustain an action that has an impermissible effect." Id. at 462 . This case was of limited precedential value, however, because liability of the affected jurisdiction had, arguably, been previously established. Emporia schools were covered by a desegregation order directed at Greensville County. Following the desegregation order in Wright v. School Board, 252 F. Supp. 378 (1966), the city of Emporia withdrew from the county school system.

24. Washington v. Davis, 426 U.S. 229, 244 (1976); see, e.g., Bridgeport Guardians, Inc. v. Members of Bridgeport Civil Serv. Comm'n, 482 F.2d 1333, 1337 (2d Cir. 1972) (de facto racial classification suspect); Kennedy Park Homes Ass'n v. City of Lackawanna, 436 F.2d 108, 114 (2d Cir. 1970) (compelling governmental interest needed to sustain zoning policy having discriminatory effecl).

25. "Standing alone [disproportionate impact] does not trigger the rule . . that racial classifications are to be subjected to the strictest scrutiny and are justifiable only by the weightiest of considerations." Davis, 426 U.S. at 242.

26. Cf. supra note 9 (suspect classifications indirect indices of intent). Notice of the changed standard was served with the shocking reversal of lower court opinions not even up for review. Davis, 426 U.S. at 244-45 n.12. 
any, would be admitted to prove invidious purpose. ${ }^{27}$ Both Davis and Village of Arlington Heights v. Metropolitan Housing Development Corporation $^{28}$ indicated the relevance of the disproportionate impact of the challenged state action to establishing an inference of purposeful discrimination. In addition, a pre-Davis distinct line of cases, using tests derived from tort law, held defendants to have intended the natural and foreseeable consequences of their actions. ${ }^{29}$ These evidentiary tools allowed courts to create a rebuttable presumption of intent and shift the burden of proof to the defendant state body. ${ }^{30}$ With the burden shifted, the failure to provide an adequate nonracial reason for state action was considered probative of intent. ${ }^{31}$ Thus, while Davis and its progeny in-

27. See Alexander, Introduction: Motivation and Constitutionality, 15 SAN DiEgo L. REV. 925, 938 (1978) (major issues are evidentiary); Simon, supra note 9, at 1130 (same).

28. 429 U.S. 252, 266 (1977) (impact of official action may provide important starting point in establishing invidious purpose) (citing Gomillion v. Lightfoot, 364 U.S. 339 (1960); Lane v. Wilson, 307 U.S. 268 (1939); Guinn v. United States, 238 U.S. 347 (1915); Yick Wo v. Hopkins, 118 U.S. 356 (1886)). A long line of pre-Davis cases supports the proposition that motives can be inferred from practices. See Keyes v. School Dist. No. 1, 413 U.S. 189, 207-08 (1973) (discrimination presumed throughout district from practice in one area); Reitman v. Mulkey, 387 U.S. 369, 373-76 (1967) (proper to examine practices over time in ascertaining motive); Griffin v. County School Bd., 377 U.S. 218, 230-32 (1964) (intent in closing county schools inferred from past segregative practices); Lane v. Wilson, 307 U.S. 268, 276 (1939) (intent of grandfather clause evident from practice of discrimination against Negro voters); Morgan v. Kerrigan, 509 F.2d 580, 592 (1st Cir. 1974) (pattern of segregative practices establishes motive), cert. denied, 421 U.S. 963 (1975); Davis v. Schnell, 81 F. Supp. 872, 880 (S.D. Ala.), aff'd per curiam, 336 U.S. 933 (1949) (intent of literacy test inferred from practice of excluding Negro voters).

29. See United States v. Texas Educ. Agency, 532 F.2d 380, 389-92 (5th Cir. 1976) ("natural, foreseeable and inevitable result"), vacated and remanded sub nom. Austin Indep. School Dist. v. United States, 429 U.S. 990 (1976); United States v. School Dist., 521 F.2d 530, 536-37 (8th Cir. 1975) (Omaha $I$ ) (presumption based on natural, probable and foreseeable consequences test), cert. denied, 423 U.S. 946 (1975), reaff'd per curiam, 541 F.2d 708, 709 (8th Cir.) (Omaha II) (en banc), vacated per curiam, 433 U.S. 667 (1976), reaf'd per curiam, 565 F.2d 127 (8th Cir. 1977) (Omaha III) (en banc); Hart v. Community School Bd., 512 F.2d 37, 50 (2d Cir. 1975) (same); Oliver v. Michigan State Bd. of Educ., 508 F.2d 178, 182 (6th Cir. 1974) (presumption of segregative purpose from foreseeable result), cert. denied, 421 U.S. 963 (1975); Morgan v. Hennigan, 379 F. Supp. 410, 479 (D. Mass. 1974) (dictum) (foreseeable segregative consequences evidence of intent), afrd sub nom. Morgan v. Kerrigan, 508 F.2d 580 (1st Cir. 1974), cert. denied, 421 U.S. 963 (1975); Fiss, School Desegregation: The Uncertain Path of the Law, 4 PHIL. \& PUB. AFF. 3 (1974); Note, Intent to Segregate: The Omaha Presumption, 44 GEO. WASH. L. REV. 775, 815 (1976); see also NAACP v. Lansing Bd. of Educ., 559 F.2d 1042 (6th Cir. 1977) (purpose inferred post-Davis from foreseeable results of school board attendance zone policies).

30. See, e.g., Alexander v. Louisiana, 405 U.S. 625, 632 (1972) (burden shifts to state to rebut presumption of unconstitutionality); Turner v. Fouche, 396 U.S. 346, 360 (1970) (same); Oliver v. Michigan State Bd. of Educ., 508 F.2d 178 (6th Cir. 1974) (following practice developed in employment discrimination cases of allowing presumption of intent to be established by objective facts and then permitting affirmative defense), cert. denied, 421 U.S. 963 (1975).

31. See, e.g., Castaneda v. Partida, 430 U.S. 482, 498-500 (1977) (failure to rebut presumption probative of intent); Washington v. Davis, 426 U.S. 229, 241 (1976) (state must rebut presumption of unconstitutionality created by prima facie case).

Allowing the failure to rebut a presumption to be probative of intent also has pre-Davis precedential support. See Alexander v. Louisiana, 405 U.S. 625, 632 (1972) (good faith defense insufficient to dispel prima facie case); Turner v. Fouche, 396 U.S. 346, 361 (1970) ("evidentiary void" in rebutting prima facie case confirms complainant's charge of discrimination); Eubanks v. Louisiana, 356 U.S. 584,587 (1958) (assertions of nondiscrimination by defendant insufficient to rebut presumption). 
creased the burden upon equal protection plaintiffs, preexisting evidentiary standards and those adopted immediately after Davis still allowed liability to be established on the basis of effects without direct evidence of subjective motive.

\section{The Impact of Bolden}

Both the scope of the intent standard and the requisite criteria for establishing discriminatory purpose were addressed in City of Mobile v. Bolden. ${ }^{32}$ Holding for the first time that invidious purpose must be proved to establish liability in a voting rights claim, a divided Court overturned and remanded a finding that at-large elections unconstitutionally diluted the votes of blacks in Mobile, Alabama. In Bolden, the intent standard was extended for the first time to claims brought under the Fifteenth Amendment and under the fundamental rights strain of the Fourteenth Amendment. ${ }^{33}$ This extension substantially redefined constitutional protections, erecting a major obstacle to equal protection litigation against institutional discrimination. ${ }^{34}$

Although the Court purported to apply an already established intent standard, its holding was, in fact, irreconcilable both with precedent and with the conventionally understood doctrinal basis of intent. Writing for

32. Six separate opinions were filed in this case. Justice Stewart authored the plurality opinion joined by Chief Justice Burger, Justice Powell, and Justice Rehnquist. The plurality reversed and remanded for proof of invidious purpose on the part of the state legislature that created Mobile's city government. City of Mobile v. Bolden, 446 U.S. 55 (1980) (plurality opinion). Justice Blackmun concurred in the result because of the scope of relief afforded plaintiffs. Id. at 83 (Blackmun, J., concurring in the result). Justice Stevens concurred in the judgment based on his view that greater deference should be accorded to the states where neutral and legitimate government activity is involved. Id. at 92 (Stevens, J., concurring in judgment). Justice White dissented on the grounds that lower court holdings were sufficient to establish invidious purpose. Id. at 95 (White, J., dissenting). Justice Marshall dissented based on his view of voting as a fundamental right not subject to the Davis intent test. Id. at 114 (Marshall, J., dissenting). Justice Brennan dissented and joined the opinions of Justices White and Marshall. Id. at 94 (Brennan, J., dissenting).

33. See infra pp. $342-44$.

34. The result of the plurality opinion is to hold plaintiffs to a threshold burden of establishing subjective motive through direct evidence. For the difficulties of establishing institutional motivation, see Washington v. Davis, 426 U.S. 229, 253 (1976) (Stevens, J., concurring) ("It is unrealistic . . . to require the victim of alleged discrimination to uncover the actual subjective intent of the decisionmaker. . . ."); Keyes v. School Dist. No. 1, 413 U.S. 189, 227 (1973) (Powell, J., concurring in part and dissenting in part) (inadequacy of any test "resting on so nebulous and elusive an element as a school board's segregative 'intent" "); Palmer v. Thompson, 403 U.S. 217, 225 (1971) (difficult for a court to ascertain motivation of a group of legislators); United States v. O'Brien, 391 U.S. 367, 383 (1968) (difficult for a court to determine motivation, or collection of different motivations, that lie behind legislative enactment); Alexander, supra note 27, at 937; Brest, supra note 2, at 120 n.124 (even intent of majority is shaky basis for constitutional doctrine since it may not be predicate for decision taken); Ely, supra note 2, at 1219-21, 1268 (only motive of majority of legislators sufficient for judicial evaluation); Annual Conference of Second Judicial Circuit, supra note 21, at 278 (institutional perspective complicates notion of intent); Comment, supra note 9, at 733 (same); Note, supra note 21 , at $332-37$ (same). 
the Bolden plurality, Justice Stewart ${ }^{35}$ went far beyond simply extending the intent standard to the voting rights context; ${ }^{36}$ his opinion completely undermined the evidentiary standards for proving intent that had evolved since Davis. ${ }^{37}$ Overruling the Fifth Circuit, ${ }^{38}$ the plurality refused to infer

35. A precursor to Justice Stewart's opinion can be found in his dissent in Kramer v. Union Free School Dist. No. 15, 395 U.S. 621, 634 (1969). In a challenge to a property requirement for eligibility to vote in school district elections, Justice Stewart argued for a rational relation test, rejecting heightened scrutiny under a fundamental rights analysis. Id. at 636-37.

36. City of Mobile v. Bolden, 446 U.S. 55 (1980) (plurality opinion). In order to arrive at this conclusion, Justice Stewart had to undertake a three-part analysis of the rights at stake: (i) Section 2 of the Voting Rights Act, 42 U.S.C. $§ 1973$ (1976), was held to do no more than elaborate on the language of the Fifteenth Amendment and therefore to add nothing to the Fifteenth Amendment claim, $j d$. at 61 ; (ii) the Fifteenth Amendment was defined to prohibit "only purposefully discriminatory denial or abridgment by government of the freedom to vote 'on account of race, color, or previous condition of servitude," id. at 65; and (iii) only purposeful discrimination was held to be a violation of the equal protection clause of the Fourteenth Amendment, id. at 66.

37. See Parker, The Impact of City of Mobile and Strategies and Legal Arguments for Voting Rights Cases in Its Wake, in ROCKEFELLER FOUNDATION CONFERENCE REPORT: THE RIGHT TO VOTE 98, 112-18 (1981) (describing evolution of pre-Bolden evidentiary standards).

Although the intent standard had not been imposed on vote dilution cases, the high threshold burden of proof in these cases closely paralleled the post-Davis factors establishing intent. See, e.g., White v. Regester, 412 U.S. 755, 766 (1973); Zimmer v. McKeithen, 485 F.2d 1297, 1305 (5th Cir. 1973) (en banc), aff'd per curiam on other grounds sub nom. East Carroll Parish School Bd. v. Marshall, 424 U.S. 636 (1976). This similarity in evidentiary standards led the Fifth Circuit panel in Bolden v. City of Mobile, 571 F.2d 238, 246 (1978), rev'd and remanded, 446 U.S. 55 (1980), to rule that satisfaction of the White and Zimmer criteria created a presumption of purpose.

White adopted the test of Whitcomb v. Chavis, 403 U.S. 124, 149-50 (1971), and held that the burden of plaintiffs was to produce

evidence to support findings that the political processes leading to nomination and election

were not equally open to participation by the group in question-that its members had less

opportunity than did other residents in the district to participate in the political processes and

to elect legislators of their choice.

412 U.S. at 766. The use of at-large voting for the Texas legislature in Dallas and Bexar counties was held to have unconstitutionally diluted the votes of blacks and Mexican-Americans based on: (i) the history of official racial discrimination in Texas; (ii) the requirement of a majority vote for nomination in a party primary; (iii) the "place" rule that guaranteed that blacks would run head-to-head against white candidates; (iv) the fact that the only two blacks elected since Reconstruction were those slated by the white-controlled Dallas Committee for Responsible Government (DCRG); and (v) the fact that the DCRG did not need electoral support from blacks and could therefore disregard their needs and aspirations. Id. at 766-67.

The Zimmer court further elaborated the factors in White:

[W] Were a minority can demonstrate a lack of access to the process of slating candidates, the unresponsiveness of legislators to their particularized interests, a tenuous state policy underlying the preference for multi-member or at-large districting, or that the existence of past discrimination in general precludes the effective participation in the election system, a strong case is made. Such proof is enhanced by a showing of the existence of large districts, majority vote requirements, anti-single shot voting provisions and the lack of provision for at-large candidates running from particular geographical subdistricts. The fact of dilution is established upon proof of the existence of an aggregate of those factors. 485 F.2d at 1305 (footnotes omitted).

38. The district court in Bolden, while rejecting application of the Davis intent standard to voting, found facts supporting the principal non-subjective evidentiary bases of intent and ruled that plaintiffs had satisfied the requirements of White and Zimmer. Bolden v. City of Mobile, 423 F. Supp. 384 (S.D. Ala. 1976), aff'd, 571 F.2d 238 (5th Cir. 1978), rev'd and remanded, 446 U.S. 55 (1980). On appeal the Fifth Circuit panel accepted defendant's argument that intent must be proved, but held that satisfaction of the White and Zimmer criteria, combined with defendant's failure to rebut those criteria and establish convincingly an adequate nonracial reason for the maintenance of at-large elec- 
intent from the totality of evidentiary factors, and, treating the concerns raised by the plaintiffs in isolation, dismissed each as a ground for imposing liability. ${ }^{30}$ Findings of discriminatory impact by the district court were dismissed as insufficient, standing alone, to support a claim of purposeful discrimination. ${ }^{40}$ The use of foreseeability was effectively eliminated by the plurality's reliance on the most restrictive aspects of Personnel Administrator v. Feeney." Past discrimination was equated with "original sin" and held to be of "limited help" in establishing purpose. ${ }^{42}$ Similarly, the inadequacy of nonracial reasons was dismissed as a line of inquiry since alternative explanations are, the plurality asserted, "almost always" available. ${ }^{43}$

tions, was sufficient to establish discriminatory purpose. 571 F.2d at 246 . On remand, 542 F. Supp. 1050 (1982), the district court again struck down at-large elections based upon invidious purpose in their adoption and discriminatory effects in their maintenance.

39. See 446 U.S. at $72-73$. The radical redefinition of the intent standard wrought by this rejection of previous evidentiary standards is highlighted by the dissent of Justice White, the author not only of Davis but also of White v. Regester, 412 U.S. 755 (1973), the leading Supreme Court opinion on at-large elections. Though written prior to the articulation of an intent standard in Davis, White $v$. Regester's totality of the circumstances evidentiary test closely paralleled the post-Davis evidentiary norms for proving purpose in the case of institutional defendants. See supra note 37. As Justice White pointed out, the Bolden plurality's redefinition of evidentiary standards was not the inevitable result of applying the intent requirement to at-large elections: "By viewing each of the factors relied upon below in isolation the plurality rejects the 'totality of the circumstances' approach we endorsed in White v. Regester, Washington v. Davis, and Arlington Heights v. Metropolitan Housing Dev. Corp." 446 U.S. at 103 (White, J., dissenting) (citations omitted).

40. The plurality opinion declared:

It may be that Negro candidates have been defeated, but that fact alone does not work a constitutional deprivation .... [E]vidence of discrimination by white officials in Mobile is relevant only as the most tenuous and circumstantial evidence of the constitutional invalidity of the electoral system under which they attained their offices. . . [T] [Te mechanics of the atlarge electoral system ... tend naturally to disadvantage any voting minority, as we noted in White v. Regester, 412 U.S. 755 . They are far from proof that the at-large electoral scheme represents purposeful discrimination against Negro voters.

446 U.S. at 73-74 (plurality opinion) (footnotes omitted).

41. 442 U.S. 256 (1979). Justice Stewart's opinion in Bolden focused on the observation in Feeney that intent implies that a decisionmaker "selected or reaffirmed a particular course of action at least in part 'because of,' not merely 'in spite of,' its adverse effects upon an identifiable group." Id. at 279 (footnote omitted). The Feeney opinion, however, immediately qualifies this by stating:

This is not to say that the inevitability or foreseeability of consequences of a neutral rule has no bearing upon the existence of discriminatory intent. Certainly, when the adverse consequences of a law upon an identifiable group are as inevitable [as those here] . . . a strong inference that the adverse effects were desired can reasonably be drawn.

Id. at 279 n.25. In Bolden, Justice Stewart disregarded this important caveat and stated simply that, "if the District Court meant that the state legislature may be presumed to have 'intended' that there would be no Negro Commissioners, simply because that was a foreseeable consequence of at-large voting, it applied an incorrect legal standard." City of Mobile v. Bolden, 446 U.S. 55, 72 n.17 (1980) (plurality opinion).

42. "[P]ast discrimination cannot, in the manner of original sin, condemn governmental action that is not itself unlawful. The ultimate question remains whether a discriminatory intent has been proved in a given case. More distant instances of official discrimination in other cases are of limited help in resolving that question." Id. at 74 .

43. The plurality noted:

[W] here the character of a law is readily explainable on grounds apart from race, as would nearly always be true where, as here, an entire system of local governance is brought into 
By stripping plaintiffs of indirect and circumstantial evidence, the plurality opinion raised major obstacles to establishing the intent of an institutional defendant. The subjective intent of corporate bodies is at best a nebulous concept, and the difficulty of defining such intent had been reflected in the Court's long-standing reluctance to determine the constitutionality of legislative motive. ${ }^{44}$

\section{The Purpose of Intent}

The Bolden plurality's radical restructuring of both the standard of liability and the evidentiary norms facing the prospective civil rights claimant necessitates an exploration of the underpinnings of the intent doctrine in equal protection law. Though less problematic than discovering the unarticulated motives of a legislative body, probing the covert implications of judicial decisions is nonetheless murky business. Brought into the light of day, however, the intent cases stand in a line of opinions, generally dissents, which express growing anxiety over the remedies available to civil rights litigants. Viewed from this vantage point, the evolution of the voting rights case law provides a fitting example of the Court's remedial concerns.

\section{A. The Court's Anxiety over the Scope of Relief}

The current tension surrounding the use of intent is best understood when viewed in the context of the Court's growing concern over the remedies available to equal protection litigants under the equitable powers of the federal courts. Under equity doctrine, the scope of the remedy is tied to the nature and extent of the violation. ${ }^{45}$ The sheer magnitude of cases and the limits of the Supreme Court's docket combine with the highly discretionary character of equitable remedies to make restraints on remedies alone highly ineffective. A far more powerful mechanism to reduce the scope of relief is to redefine what constitutes a violation.

This concern is most directly addressed by Justice Blackmun's concurrence in Bolden. Justice Blackmun took no position on whether intent need be proved, accepted Justice White's contention that, if so, it had been in that case, ${ }^{46}$ and yet concurred in the result-a reversal of the lower

question, disproportionate impact alone cannot be decisive, and courts must look to other evidence to support a finding of discriminatory purpose. Id. at 70 .

44. See Brest, supra note 19 , at 26.

45. See infra pp. 337-38.

46. "Assuming that proof of intent is a prerequisite to appellees' prevailing on their constitutional claim of vote dilution, I am inclined to agree with $\mathrm{Mr}$. Justice White that, in this case, "the findings of the district court amply support an inference of purposeful discrimination." " 446 U.S. at 80 (Blackmun, J., concurring in result). 
courts' findings of liability:

I concur in the Court's judgment of reversal, however, because I believe that the relief afforded appellees by the District Court was not commensurate with the sound exercise of judicial discretion. . . . [E]ven a temporary alteration of a long-established form of municipal government is a drastic measure for a court to take. ${ }^{47}$

The systematic exclusion of the previously established evidentiary bases of intent in a remand on liability is thus coupled with a direct indictment of the lower federal courts for overstepping the bounds of equity. Although remanding on the basis of liability, the plurality opinion also suggested concern about the scope of relief; it emphasized both the prevalence of atlarge municipal elections in the United States" ${ }^{48}$ and the fact that "an entire system of local governance is brought into question." 40 The plurality remand, however, because it was based on liability, did not need to dwell on the scope of relief.

The Court's concern with the scope of relief in equal protection cases actually antedated Bolden. The controversy surrounding school busing orders in the early 1970 's" prompted a popular chorus of "judicial restraint," ions. Writing in dissent in Columbus Board of Education v. Penick, ${ }^{52}$ Justice Powell, the most outspoken member of the Court on this issue, accused the Court of being "remarkably insensitive to the now widely accepted view that ... the federal judiciary should be limiting rather than expanding the extent to which courts are operating the public school systems of our country."'ss But, as Professor Bell has noted, "Whatever the accuracy of this interpretation [the Court's actual concern with broad remedies], the lower courts seemingly received quite the opposite message." 14

Looking back from the perspective of Bolden, a trend is clearly discernible. Prior to the adoption of the intent test, it was established judicial doctrine that once liability was found, courts had broad discretion in

47. Id. at 80-82 (Blackmun, J., concurring in result).

48. Id. at $60 \mathrm{n} .7$ (plurality opinion).

49. Id. at 70 (plurality opinion).

50. See J.H. WILKINSON, FROM BROWN TO BAKKE 203-15 (1979) (discussing explosive Boston events surrounding court-ordered busing).

51. See, e.g., Glazer, Should Judges Administer Social Services?, 50 PUB. INTEREST 64 (1978); Taylor, Bar Urged to Join Fight on Politics in the Courts, N.Y. Times, Jan. 26, 1982, at B8, col. 1 (report of Attorney General Smith's attack on courts' "political policy making").

52. 443 U.S. 449 (1979).

53. Id. at $479-80$.

54. D. BELL, RACE, RACISM AND AMERICAN LAW 405 (2d ed. 1980). 
framing equitable relief. ${ }^{55}$ As articulated in a voting practice case: "[T]he court has not merely the power but the duty to render a decree which will so far as possible eliminate the discriminatory effects of the past as well as bar like discrimination in the future." ${ }^{\text {"s6 }}$ Milliken $I{ }^{57}$ which in 1974 ordered the first reversal of a lower court desegregation order since Brown v. Board of Education, ${ }^{58}$ introduced open concern with the scope of relief into the Court's opinions. As expressed by the majority in Hills v. Gautreaux, ${ }^{\mathbf{B 8}}$ the reversal in Milliken I was "based on fundamental limitations on the remedial powers to restructure the operation of local and state governmental entities."

In the aftermath of Washington v. Davis, four lower court decisions ordering school desegregation were remanded to establish liability in light of the intent standard. ${ }^{81}$ In Austin Independent School District v. United States, ${ }^{62}$ despite the remand, Justice Powell authored a long concurrence, joined by Chief Justice Burger and Justice Rehnquist, that focused on the use of busing as a remedial tool. ${ }^{63}$ Other opinions that focus on the scope of relief though deciding questions of liability include Justice Rehnquist's dissent in Dayton Board of Education v. Brinkman, ${ }^{64}$ Chief Justice Burger's opinion in Milliken $I^{65}$ Justice Powell's dissent in Columbus, ${ }^{68}$ and the per curiam opinion in Omaha $I{ }^{67}$

These initial attempts to curtail remedies were based upon a restrictive definition of liability under the intent doctrine. Lower federal courts were then ordered to match relief to the narrow violation. ${ }^{68}$ Again it was Jus-

55. In Swann v. Charlotte-Mecklenburg Bd. of Educ., 402 U.S. 1, 15 (1971), the Court declared: "[T]he scope of a district court's equitable powers to remedy past wrongs is broad, for breadth and flexibility are inherent in equitable remedies." In a companion case, the Court added that "the measure of any desegregation plan is its effectiveness." Davis v. Board of School Comm'rs, 402 U.S. 33, 37 (1971).

56. United States v. Louisiana, 380 U.S. 145, 154 (1965).

57. Milliken v. Bradley, 418 U.S. 717 (1974).

58. 347 U.S. 483 (1954).

59. 425 U.S. 284 (1976).

60. Id. at 293.

61. Brennan v. Armstrong, 433 U.S. 672 (1977) (school desegregation order remanded in light of Arlington Heights to establish intent); School Dist. v. United States, 433 U.S. 667 (1977) (racially disproportionate impact not sufficient; intent must be proved); Board of School Comm'rs v. Buckley, 429 U.S. 1068 (1976); Austin Indep. School Dist. v. United States, 429 U.S. 990 (1976).

62. 429 U.S. 990 (1976).

63. Id. at 991 (issue of remedy included in remand because of extensive nature of lower court relief order).

64. 443 U.S. 526, 544 (1978) ("meting out of equal remedies" for school desegregation unwarranted).

65. 418 U.S. 717, 743-44 (1974) (remedial supervision of school systems is task for which judges are not qualified).

66. 443 U.S. 449,483 (1979) (remedial orders typify intrusions upon local authorities that adversely effect quality of education).

67. School Dist. v. United States, 433 U.S. 667, 668-69 (1977) (remanding case to determine incremental segregative effect of violations and order remedy accordingly).

68. Contrast the Keyes presumption, which inferred intent and therefore liability throughout a 
tice Powell who tied this directly to an open indictment of equitable remedies. Dissenting from the dismissal of certiorari in Estes v. Metropolitan Branches of Dallas NAACP, ${ }^{69}$ decided the same Term as Bolden, and joined by Justices Stewart and Rehnquist, he wrote:

[T]his case presents a long-needed opportunity to re-examine the considerations relevant to framing a remedy in a desegregation suit. . . . The District Court failed to identify the link between the constitutional violation and the desegregation remedy. ... Unless courts carefully consider those issues, judicial school desegregation will continue to be a haphazard exercise of equitable power that can, "like a loose cannon, .... inflict indiscriminate damage" on our schools and communities. ${ }^{70}$

Writing in 1980, Professor Derrick Bell noted the Court's concern with remedy when considering liability in the immediate post-Davis period:

Reading between the lines of the Supreme Court's remands during the 1976-1977 Term, it appeared that while discussing the standard of liability that the lower courts should require, the Court actually was expressing concern about the cost and disruptiveness of the remedies which were entered. ${ }^{71}$

\section{B. Eliminating Remedies}

The hostility to the scope of remedies available to the successful equal protection litigant threatened to erupt into a doctrinal broadside against the remedial powers of federal courts, as occurred in the Bolden plurality opinion. Any attempt to bar remedies altogether, however, necessarily entails a fundamental alteration of the substantive constitutional doctrine. Thus, the evolution of the intent doctrine and its associated evidentiary burdens is best understood as a contrivance to confine the federal judiciary in matters of equal protection relief. ${ }^{72}$ The intent standard is a particu-

school district if it could be established in any subdivision, with the narrow emphasis on liability limited to the jurisdiction in which intent could be established in Milliken $I$, or limited to the actual perpetrator of the unconstitutional act in Rizzo v. Goode, 423 U.S. 362 (1976).

69. 444 U.S. 437 (1980) (Powell, J., dissenting from dismissal of certiorari).

70. Id. at 445. While Justice Powell's remarks in Estes were directed at school desegregation orders, they have clear implications for any broad equitable relief. As noted in Swann v. CharlotteMecklenburg School Dist., 402 U.S. 1, 15-16 (1971), school desegregation orders do "not differ fundamentally from other cases involving the framing of equitable relief."

71. D. BELL, supra note 54, at 405 . Professor Karst writes in a similar vein: "The preoccupation has been with issues such as the asserted invasion by the judiciary of the legislative province, with doubts concerning judicial competence to understand and decide certain kinds of questions or provide certain kinds of remedies (notably those involving the imposition of affirmative duties on the states) ...." Karst, supra note 10 , at $4 \mathrm{n} .16$.

72. The intent doctrine is ill suited to the reality of race relations in the United States. The legacy of slavery, the pervasiveness of de jure segregation only a generation ago, the bitter racism that still 
larly powerful mechanism to restructure the relationship between the civil rights litigant and federal courts for three reasons.

First, intent differs from comity ${ }^{73}$ abstention, ${ }^{74}$ deference, ${ }^{75}$ and federalism ${ }^{76}$-doctrines that have also come to the fore in the past decade-in that the latter only curtail the availablity of the federal forum. Each of these doctrines addresses the capacity of a litigant to get into federal court, and the relationship between the remedies available through federal court and those that can be obtained in state court or state administrative proceedings. An intent standard, by contrast, redefines the constitutional violation and thus restricts the relief available.

Second, in establishing liability, an intent standard raises serious problems of proof. Although this difficulty arises in many contexts, it is compounded when the defendant state agent is a state legislature rather than an individual administrator. Simply put, it is in dealing with corpo-

infects every pore of American politics and society, the continued concentration of blacks at the bottom of the proverbial ladder - all these defy characterization as innocent state action that perpetuates or aggravates racial oppression. The notion of allegedly innocent acts disadvantaging blacks is persuasively challenged by Professor Lawrence:

Once the state has effectively institutionalized racial segregation as a labeling device, only minimal maintenance is required to keep it in working order. Once the system is established, any attempt to distinguish "active" governmental involvement in racial segregation from "passive" or "neutral" tolerance of private segregation is illusory. Present passivity is merely a continuation of past action.

Lawrence, Segregation Misunderstood, 12 U.S.F. L. REV. 15, 40 (1977). The same theme appears in Justice Powell's Keyes opinion: "Indeed, if one goes back far enough, it is probable that all racial segregation, wherever occurring and whether or not confined to the schools, has at some time been supported or maintained by government action." Keyes v. School Dist. No. 1, 413 U.S. 189, 228 n.12 (1973) (Powell, J., concurring in part and dissenting in part).

The intent doctrine unrealistically supposes that government entities are unaware of the probable racial consequences of their actions. See Simon, supra note 9, at 1111. The point is brought home by Professor Karst:

If we were talking about some new form of discrimination-say, discrimination against persons with red hair, or discrimination against whites-then the "purpose" doctrine would make eminent sense, as would its corollary view that stigmatic harm can result only when there is a purpose to cause it. But in America today, where the problem of racism is the problem of eliminating a long-established stigma of inferiority . . . it is as plain as a cattle prod that we are talking about something quite different. A legislature oblivious to this existing stigma of caste will nonetheless reinforce the stigma when it produces racially discriminatory effects through ostensibly "neutral" legislation.

Karst, supra note 10 , at 51 .

73. See, e.g., Mitchum v. Foster, 407 U.S. 225, 243 (1972) (discussing "the principles of equity, comity, and federalism that must restrain a federal court"); Younger v. Harris, 401 U.S. 37, 44 (1971) (courts should be restrained by comity, "a proper respect for state functions").

74. See, e.g., Trainor v. Hernandez, 431 U.S. 434, 444 (1977) (abstention in civil suits in which state is a party); Colorado River Conservation Dist. v. United States, 424 U.S. 800, 814-16 (1976) (abstention in favor of state court proceedings); Huffman v. Pursue, Ltd., 420 U.S. 592, 604 (1975) (abstention in state civil proceedings akin to criminal prosecution); Younger v. Harris, 401 U.S. 37, 43-44 (1971) (federal court abstention in state criminal prosecutions).

75. See Huffman v. Pursue, Ltd., 420 U.S. 592, 604 (1975) (deference to state court's ability to protect constitutional rights).

76. See Rizzo v. Goode, 423 U.S. $362,378-80$ (1976) (federalism weighs heavily against injunctive relief against a state). 
rate state bodies, as opposed to individuals, that subjective motive is the most difficult to prove and the easiest to mask. ${ }^{77}$ Moreover, it is against just such corporate bodies that broad-scale relief is the likely result of a finding of liability. By allowing only direct evidence of subjective motive, the Bolden plurality effectively insulated the actions of corporate bodies-the municipality, ${ }^{78}$ the legislature, or the popular referendum $^{7 \theta}$-from judicial review. A legislature assured that only direct evidence in the record will be admissible proof of invidious purpose will surely cast electoral redistricting in terms of "efficient government" and school redistricting in terms of "good education," regardless of its actual motivation. ${ }^{80}$ Even inferential proof of intent is insufficient when the challenged practice is a long-lasting one requiring a minimum of maintenance to preserve its discriminatory effects.

Third, combined with the already established doctrine that the remedy must be strictly tailored to the violation, ${ }^{\mathbf{8 1}}$ the redefinition of liability in terms of intent rather than impact ${ }^{82}$ may preclude remedies even in cases where intent can be proved. In strictly tailoring a remedy to a finding of liability based on intent, a court might limit itself to effectuating only that which would have occurred but for the illicit motive, ${ }^{83}$ and thereby allow a defendant to show that "it would have reached the same decision" for

77. See Alexander, supra note 27 , at 937-38.

78. See City of Memphis v. Greene, 451 U.S. 100 (1981) (street closing preventing black motorists traversing white neighborhood not intended to discriminate).

79. See Kirksey v. City of Jackson, 663 F.2d 659 (5th Cir. 1981), on reh'g, 669 F.2d 316 (1982). The Kirksey court added a new twist to equal protection litigation by holding the motives of voters to be beyond judicial examination on First Amendment grounds. On rehearing the Fifth Circuit backed off and declared that in a "proper case" motivation may be explored. No definition of a "proper case" was given. 669 F.2d at 316 .

80. By assuring state bodies that only direct statements indicating intent will prompt federal court review, the Court provides an incentive to police only what appears in official records. As the Fifth Circuit observed: "[T]here will be no "smoking gun." "Lodge v. Burton, 639 F.2d 1358, 1363 n.8 (5th Cir. 1981), aff'd sub nom. Rogers v. Lodge, 102 S. Ct. 3272 (1982). Where, however, the form of judicial relief sought is simply a cease and desist order against the application of a facially neutral ordinance by an individual administrator, the equal protection litigant's burden may still be manageable-subjective motivation is easier to ascertain in such cases than in the case of a corporate body. Cf. Yick Wo v. Hopkins, 118 U.S. 356 (1886) (striking down selective prosecution of ChineseAmericans).

81. See City of Mobile v. Bolden, 446 U.S. 55, 82 (1980) (Blackmun, J., concurring in result).

82. Were intent to be established according to the standard of the Bolden plurality, constitutional liability would stem from the motives of the Alabama state legislature rather than the systematic exclusion of blacks from elected office in Mobile.

83. The principal advocate of a but-for standard of liability under the intent doctrine is Professor Samford. See Samford, supra note 11. He does not, however, confine remedy to the but-for origin of liability. Professor Eisenberg, on the other hand, favors adoption of a but-for and proximate cause test, but irrespective of the question of motive. See Eisenberg, supra note 2, at 58-69, 94.

For a discussion of the opposition to the use of a but-for standard for equal protection doctrine, see Brest, supra note 2, at 130-31; Note, Discriminatory Purpose and Disproportionate Impact: An Assessment After Feeney, 79 ColUM. L. REV. 1376, 1407 (1979); The Supreme Court, 1979 Term, 94 HARV. L. REV. 75, 147 (1980). 
other valid reasons. ${ }^{84}$

\section{G. The Intent Standard Applied to Fundamental Rights}

The obstacles to a successful equal protection claim under the intent standard apply regardless of the doctrinal basis of the claim. In the case of the fundamental rights strain of the doctrine, however, the obstacles are still greater since the source of the constitutional claim is not the explicit or implicit purpose of the classification mechanism. Thus, prior to Bolden, intent analysis had not been applied to cases that involved the abridgement of fundamental rights. ${ }^{85}$ Davis itself made no mention of the fundamental rights line of Fourteenth Amendment decisions; it held a finding of intent necessary only in the context of challenges based on discriminatory treatment of a suspect class. ${ }^{86}$ Similarly, the line of intent decisions between Davis and Bolden was confined to cases involving no constitutional entitlement. ${ }^{87}$ The subsequent imposition of an intent standard in the area of fundamental rights is consistent with the Court's attempts to limit the

84. Mt. Healthy School Dist. v. Doyle, 429 U.S. 274, 287 (1977). Mt. Healthy involved the proper treatment of state administrative decisions motivated both by a legitimate and discriminatory purpose-in particular the discharge of a teacher because, at least in part, of an exercise of First Amendment rights. The broader issue was how much invidious motive would be required to invalidate state action.

For discussion of the problems of mixed motive and the difficulty involved in pinpointing the illicit motives which are sufficient to overturn legislation, see City of Mobile v. Bolden, 446 U.S. 55, 92-93 (1980) (Stevens, J., concurring in judgment) (systems that disadvantage minorities should not be sustained simply because no motive can be proved); Village of Arlington Heights v. Metropolitan Hous. Dev. Corp., 429 U.S. 252, 265 (1977) (rarely is legislature motivated by single purpose); Washington v. Davis, 426 U.S. 229, 253 (1976) (Stevens, J., concurring) (legitimate state action not unconstitutional because of motive of one legislator voting in favor); McGinnis v. Royster, 410 U.S. 263, 276-77 (1973) (search for purpose elusive enough without trying to ascertain primacy); Palmer v. Thompson, 403 U.S. 217, 225 (1971) (difficult or impossible for any court to determine sole or dominant motivation behind choices of group of legislators); Brest, supra note 2, at 126 (judicial review based on intent may spark attempts to conceal motive); Eisenberg, supra note 2, at 116-17 (summarizing objections to intent standard); Ely, supra note 2, at 1215-57, 1280 (exploring difficulty of judicial administration of intent test).

85. See City of Mobile v. Bolden, 446 U.S. 55, 113-14 (1980) (Marshall, J., dissenting).

86. Washington v. Davis, 426 U.S. $229,241-42$ (racial classifications subject to strict scrutiny upon establishment of invidious discriminatory purpose).

87. See City of Mobile v. Bolden, 446 U.S. 55, 114 (1980) (Marshall, J., dissenting). Washington v. Davis, 426 U.S. 229 (1976), involved the use of tests in the hiring of police officers in Washington, D.C. Village of Arlington Heights v. Metropolitan Hous. Dev. Corp., 429 U.S. 252 (1977), dealt with the validity of residential zoning regulations that prevented the construction of low- and moderate-income housing. Neither federal employment nor housing is subject to an affirmative constitutional entitlement.

Until Davis, both fundamental rights and suspect classifications were judged under strict scrutiny. Consequently, there was little need or incentive to sort out the different strains of equal protection analysis. See The Supreme Court, 1979 Term, supra note 83, at $143 \mathrm{n} .42$. Thus, for example, in both White v. Regester, 412 U.S. 755 (1973), and Whitcomb v. Chavis, 403 U.S. 124 (1971), in which plaintiffs were minority groups, the decisions did not clearly distinguish whether the claims were analyzed as involving suspect classification status or fundamental rights. Davis shifted the presumptions against suspect classification litigants and thus brought the potential difference between the two strains into sharp relief. 
scope of equal protection remedies.

Justice Marshall's Bolden dissent argued that the plurality's application of an intent standard to a vote dilution claim was a unique and mistaken intrusion into the fundamental rights area. ${ }^{88}$ That view is made more compelling when intent is placed in the context of the two-tier scrutiny out of which it developed. Purposeful discrimination is an inherent aspect of every suspect classification case; such discriminatory classification is the articulated intent of the statute or other state action. With the gradual disappearance of explicit racial classifications, the focus of equal protection litigation shifted to cases involving actions that were facially neutral but had a disadvantageous impact on suspect classes. In such cases, proof of intent to disadvantage a suspect class can be seen as a proxy for the explicit intent of a suspect classification in providing a basis for strict scrutiny. As noted by Professor Ely, "Disproportionate racial impact is usually the best evidence that race has been employed as the criterion of selection. This frequent conjunction . . . is doubtless one reason courts generally, like the Court in Gomillion [v. Lightfoot ${ }^{88}$ ], have failed to indicate which factor triggers the judicial response."90

The fundamental rights doctrine, on the other hand, does not address facial discrimination. It was designed instead to delineate protected spheres in which discriminatory state action would always be suspect, regardless of the classification mechanism. Under traditional fundamental rights analysis, strict scrutiny did not follow from discriminatory intent but from impact upon protected rights, abridgement of which necessitated a compelling state interest. ${ }^{\text {"1 }}$ Thus, Professor Ely notes: "Where what is denied is something to which the complainant has a substantive constitutional right-either because it is granted by the terms of the Constitution, or because it is essential to the effective governing of a democratic government-the reasons it was denied are irrelevant."

Vote dilution infringes upon substantial constitutional rights. ${ }^{93}$ Justice Stewart admitted as much in Bolden: "[T]he Equal Protection Glause

88. 446 U.S. at 114 (Marshall, J., dissenting).

89. 364 U.S. 339 (1960) (city annexation struck down where it had effect of diluting black votes and where there was inference of discriminatory motive from "uncouth" 28-sided city line).

90. Ely, supra note 2, at 1254 .

91. See supra note 5 .

92. Ely, The Centrality and Limits of Motivation Analysis, 15 SAN DIEGo L. REv. 1155, 1161 (1978). Professor Ely adds, "It would be a tragedy of the first order were the Court to expand its burgeoning awareness of the relevance of motivation into the thoroughly mistaken notion that a denial of a constitutional right does not count as such unless it was intentional." Id.

93. For discussion of the fundamental centrality of the right to vote, see Harper v. Virginia Bd. of Elections, 383 U.S. 663, 670 (1966); Reynolds v. Sims, 377 U.S. 533, $561-62$ (1964); Yick Wo v. Hopkins, 118 U.S. 356, 370 (1886); J. ELY, supra note 9, at 135-36; Karst, supra note 10, at 27-29; Note, Racial Vote Dilution in Multi-member Districts: The Constitutional Standard After Washington v. Davis, 76 MiCH. L. REV. 694, 720-26 (1978). 
confers a substantive right to participate in elections on an equal basis with other qualified voters." ${ }^{\text {"94 }}$ The right at stake in vote dilution cases has been summarized elsewhere as that of a "fair chance' of influencing the political process." 95 Its starting point is the declaration in Reynolds $v$. $S^{S i m s}{ }^{96}$ of every citizen's "inalienable right to full and effective participation in the political processes of his State's legislative bodies." 97 As noted by Justice Marshall in his Bolden dissent, Fortson v. Dorsey ${ }^{98}$ and Burns v. Richardson ${ }^{2 \theta}$ indicated that at-large elections would violate that right if "designedly or otherwise" they operated to "minimize or cancel out the voting strength of racial or political elements of the voting population."100

The Bolden plurality's insistence on proof of intent in a vote dilution case is not supported by precedent. While the "totality of the circumstances" test in White v. Regester ${ }^{101}$ can be seen as adumbrating a later intent standard, there is, for example, no foundation for Justice Stewart's characterization of White as "strongly indicating that only a purposeful dilution of the plaintiff's vote would offend the Equal Protection Clause."102 The opinion in White refers alternately to the purpose and effects of vote dilution without articulating their relationship. ${ }^{103}$ Equally unsupported is Justice Stewart's contention that "our decisions, moreover, have made clear that action by a State . . . violates the Fifteenth Amendment only if motivated by a discriminatory purpose." 104 The cases cited to support this proposition indicate only that invidious purpose may be sufficient to constitute a violation of the Fifteenth Amendment, not that it is a precondition for liability. ${ }^{105}$

94. City of Mobile v. Bolden, 446 U.S. 55, 77 (1980) (plurality opinion). It may be, as Justice Marshall claimed in dissent, 446 U.S. at 113, that because the plaintiffs in Bolden were black the plurality applied the intent standard as if it were a suspect classification case. Justice Stewart's acknowledgment, however, of the constitutional entitlement renders such analysis illegitimate since this would implicate the fundamental rights strain of the doctrine.

95. The Supreme Court, 1979 Term, supra note 83, at 145 n.58.

96. 377 U.S. 533 (1964).

97. Id. at 565 .

98. 379 U.S. 433 (1965).

99. 384 U.S. 73 (1966).

100. City of Mobile v. Bolden, 446 U.S. 55, 108 (1980) (Marshall, J., dissenting) (quoting Fortson v. Dorsey, 379 U.S. 433, 439 (1965))

101. 412 U.S. 755,769 (1973).

102. Bolden, 446 U.S. at 69 (plurality opinion).

103. White focused on the "totality of the circumstances" to determine whether the Dallas and Bexar counties' electoral systems unconstitutionally diluted minority voting strength. The Court threw out at-large elections despite admitting that the specific attributes of the electoral system were "neither in themselves improper nor invidious." 412 U.S. at 766.

104. Bolden, 446 U.S. at 62 (plurality opinion).

105. See Wright v. Rockefeller, 376 U.S. 52, 58 (1964) (no ruling on whether de facto discriminatory redistricting did or could exist); Gomillion v. Lightfoot, 364 U.S. 339, 340-41 (1960) (redistricting Tuskegee, Ala., with goal and effect of disenfranchising Negro citizens unconstitutional; no claim that motive was necessary); Guinn v. United States, 238 U.S. 347, 364-65 (1915) (purpose and effect of literacy test grounds for striking it down); see also The Supreme Court, 1979 Term, supra 


\section{Voting Rights Claims: Rights and Remedies}

An examination of the voting rights context from which the Bolden opinion arose underscores the central analytic point of this Note. Successful claims of vote dilution necessarily involve the judiciary in broad remedial actions against state electoral systems, including the possibility of overturning electoral results.

Thus, Justice Stewart's acknowledgment in Bolden of the substantive constitutional rights at stake in vote dilution cases, coupled with his application of a severe intent test, is perhaps less paradoxical when viewed against the Court's longstanding hesitation to invalidate at-large election schemes, ${ }^{108}$ and its refusal to hold them unconstitutional per se. ${ }^{107}$ The Court's vote dilution decisions may reflect an unspoken concern that no easily managed judicial standard for measuring adequate representation of minorities-one comparable to the one person, one vote test enunciated in Reynolds v. Sims ${ }^{108}$ for reapportionment cases-is available. In fact, Jus-

note 83 , at $143 \mathrm{n} .43$ (cases cited by plurality opinion showed discriminatory purpose sufficient but not necessary for claim).

106. Prior to Rogers v. Lodge, 102 S. Ct. 3272 (1982), only one Supreme Court case, White v. Regester, 412 U.S. 755 (1973), had found an at-large election to be in violation of constitutional rights. While conceding that multimember districts may enhance the voting strength of majorities, the Court has been wary of constitutionalizing the outcome of elections. No decision has guaranteed the election of any particular candidate or representative of any particular group. "As our system has it, one candidate wins, the others lose." Whitcomb v. Chavis, 403 U.S. 124, 153 (1971).

The uneasiness over the nature of the rights involved, see, e.g., United Jewish Orgs. v. Carey, 430 U.S. 144, 166-67 (1977) (no right to proportional representation by race or other group characteristic); White v. Regester, 412 U.S. 755, 765-66 (1973) (same); Whitcomb v. Chavis, 403 U.S. 124, 14957 (1971) (same), resulted in elevated burdens of proof specific to vote dilution cases, see White, 412 U.S. at 766; Zimmer v. McKeithen, 485 F.2d 1297, 1305 (5th Cir. 1973) (en banc), afTd per curiam on other grounds sub nom. East Carroll Parish School Bd. v. Marshall, 424 U.S. 636 (1977). As stated by the Court in Whitcomb v. Chavis, "[W]e have insisted that the challenger carry the burden of proving that multi-member districts unconstitutionally operate to dilute or cancel the voting strength of racial or political elements. We have not yet sustainted such an attack." 403 U.S. at 144.

107. See Kilgarlin v. Hill, 386 U.S. 120 (1967) (per curiam) (Texas reapportionment containing multimember districts upheld); Burns v. Richardson, 384 U.S. 73 (1966) (equal protection clause does not require single-member districts); Forston v. Dorsey, 379 U.S. 433 (1965) (no constitutional requirement that all districts be single-member).

108. 377 U.S. 533 (1964). The concern over justiciable standards in voting rights claims is a recurrent one. Professor Ely argues that considerations of administrability were central to the adoption of the Reynolds one person, one vote rule. J. ELY, supra note 9, at 123-25; see also Fletcher, The Discretionary Constitution: Institutional Remedies and Judicial Legitimacy, 91 YALE L.J. 635, 66473 (1981) (one person, one vote malapportionment standard molded to fit judiciary's institutional needs).

Some evidence of concern over justiciability can be found in the specific invocation in Justice Stewart's Bolden opinion of the widespread use of at-large elections as weighing against judicial intervention. 446 U.S. at 60 n.7 (plurality opinion). Prevalence alone, however, does not immunize a practice from judicial review and possible reversal; court rulings ordering the desegregation of schools faced the entrenched practice of racially separated education throughout the states of the former Confederacy. Moreover, it is a perverse notion that the widespread use of at-large elections should generate deference toward them. The fundamental character of the rights at stake and the prevalence of the practice in jurisdictions that had de jure segregation argue for greater judicial solicitude, rather than deference. See Parker, supra note 37, at 109. Even those who advocate limiting judicial intervention to process distortions allow for special solicitude in the case of state action that threatens the democratic process 
tice Stevens' concurrence in Bolden ${ }^{109}$ and his dissent in Rogers $^{110}$ specifically invoke such concern over justiciability.

Whatever the extent of the Court's concern over problems of justiciability, the effect of Bolden was to establish an unattainable standard of liability. Because election systems are invariably adopted by large legislative bodies or by referenda, a rule against evaluating intent inferentially bars the establishment of liability, and, a fortiori, eliminates the possibility of a successful vote dilution claim against an at-large election system. This approach effectively treats vote dilution as a political question, leaving its resolution to the political process by ensuring that the standard for judicial action can never be met. But such deference is absurd on its face; the vindication of voting rights can hardly be trusted to the very representatives whose election is the result of the alleged vote dilution. ${ }^{111}$ If the Court is motivated by a genuine wish to encourage the "political settlements"112 of the historic and ongoing effects of discrimination, it can do so only by first ensuring that blacks have adequate access to the political process. ${ }^{113}$

as a whole. See J. ELY, supra note 9, at 73-104; L. TRIBE, AMERICAN CONSTITUTIONAL LAW § 13-1 (1978).

In addition, the plurality opinion fails to note the mounting evidence that at-large elections together with gerrymandering and malapportionment have been used to dilute black votes. Bass, Election Laws and Their Manipulation to Exclude Minority Votes, in ROCKEFELLER FOUNDATION CONFERENCE REPORT: THE RIGHT TO VOTE 1, 8 (1981); Parker, supra note 37, at 109-10. As noted by Jack Bass, "In recent years, Southern historians have begun to document and emphasize that reforms of the Progressive movement became tools to achieve disenfranchisement in the South. According to one of them, 'the official work of undoing Reconstruction was concluded in the midst of the 20th Century's first reform movement." " Bass, supra, at 19. The adoption of at-large elections occurred alongside the combination of racism and reform that characterized the period in the South. "The blind spot in the Southern progressive record . . . was the Negro, for the whole movement in the South coincided paradoxically with the crest of the wave of racism . . . Racism was conceived of by some as the very foundation of Southern progressivism." C.V. WOODWARD, THE STRANGE CAREER OF JIM CROW 91 (3d ed. 1974).

109. 446 U.S. at 93 n.15 (Stevens, J., concurring in judgment). Justice Stevens specifically relies on the notion of the conservation of judicial resources proposed by Justice Frankfurter in Baker v. Carr, 369 U.S. 186, 267-70 (1962) (Frankfurter, J., dissenting) (court rulings on matters of discretionary state action would entangle judiciary in political thicket and threaten legitimacy).

110. Rogers v. Lodge, 102 S. Ct. 3272, 3285 (1982) (Stevens, J., dissenting).

111. See Bolden v. City of Mobile, 423 F. Supp. 384, 390-95 (S.D. Ala. 1976), affd, 571 F.2d 238 (5th Cir. 1978), rev'd and remanded, 446 U.S. 55 (1980). The district court's findings showed discrimination to exist not simply in the electoral mechanism devised for selection of the city council, but throughout an entire range of social services and municipal decisions. Few blacks were employed in higher levels of city service. The city was under court order to desegregate its police and fire departments. Black neighborhoods had inferior roads, sewers, drainage, and sidewalks. In general the Court found: "[T]here is a singular sluggishness and low priority in meeting these particularized black neighborhood needs when compared with a higher priority of temporary allocation of resources when the white community is involved." Id. at 392 .

112. Baker v. Carr, 369 U.S. 186, 267 (1962) (Frankfurter, J., dissenting).

113. There is no reason to believe that direct proof of subjective motive is the only judicially manageable standard for vote dilution. Judicially manageable standards for constitutionally impermissible institutional discrimination have been successfully applied in other contexts. Presumptions have been permitted in equal protection litigation involving a history of de jure discrimination. In school 
The Bolden plurality's insistence upon direct evidence of intent provoked an immediate outcry from commentators, ${ }^{114}$ Congress, ${ }^{115}$ and at least one lower federal court. ${ }^{116}$ Further confirming the central remedial concern of Bolden, on July 1, 1982, only two days after Congress restored the statutory Voting Rights Act remedies the Bolden plurality had removed, ${ }^{117}$ the Supreme Court backed off from the most restrictive implica-

desegregation cases, for example, the Court has allowed the existence of pre-Brown state-ordered segregation to impose an affirmative duty to desegregate and to create a presumption of unconstitutionality against post-Brown de facto segregation. See Green v. County School Bd., 391 U.S. 430, 437-38 (1968). $\Lambda$ similar presumption could be adopted against jurisdictions that show effects of vote dilution, which have a history of pre-Voting Rights Act (1965) discriminatory voting registration practices or which are covered by section 5 of the Voting Rights Act, 42 U.S.C. $\$ 1973 \mathrm{c}$ (1976). Such a standard would strike down practices that perpetuate or aggravate a history of discrimination, without imposing a per se rule against at-large elections, and was in fact adopted by the Fifth Circuit in Kirksey v. Board of Supervisors, 554 F.2d 139 (en banc), cert. denied, 434 U.S. 968 (1977). In that challenge to a Mississippi county redistricting plan, the court ruled that "a redistricting plan is constitutionally impermissible as racially discriminatory if it is a racially motivated gerrymander or if it perpetuates an existent denial of access by the racial minority to the political process." Id. at 142.

In addition, application of an intent standard to all equal protection claims exacerbates problems of justiciability. Subjective intent to discriminate is a particularly unattractive label that judges are often reluctant to attach to government officials. Subjective intent is also difficult to prove, especially in multimember bodies, and easy to obscure, particularly as decisionmakers become aware of the legal standard being applied.

The Court's peregrinations on the use of intent have been carefully mapped out by Professor Eisenberg and demonstrate that problems of justiciability are simply accentuated:

An examination of the decisions in the thirteen years since Griffin reveals the magnitude of the Court's confusion about motive. In Griffin, the Court expressly relied on motive. In Palmer, the Court said it did not rely on motive in Griffin. In Palmer and in O'Brien, the Court stated that it would not rely on motive, and, in a short-lived explanation, declared that only impact mattered. In Washington, the Court partially retreated from the Palmer-O'Brien rhetoric, offered a shallow explanation of Palmer, and indicated a willingness to rely on discriminatory motives. In Arlington Heights, the Court completed the circle by returning in substantial part to the Griffin position on motive. This chaos stems from the Court's failure to articulate why motive is relevant in constitutional adjudication.

Eisenberg, supra note 2, at 113 (citations omitted).

114. See, e.g., Parker, supra note 37; Comment, City of Mobile v. Bolden: A Setback in the Fight Against Discrimination, 47 BROOKLYN L. REV. 169 (1980); Note, City of Mobile, Alabama v. Bolden: The Requirement of Discriminatory Intent in Vote Dilution Claims, 32 BAYLOR L. REV. 639 (1980); The Supreme Court, 1979 Term, supra note 83, at 138; Note, Voting Rights: Stuck Inside of Mobile with the Voting Blues Again. Vote Dilution Claims Confined, 10 STETSON L. REV. 363 (1981).

115. See S. REP. NO. 417, 97th Cong., 2d Sess. 2 (1982). Discussing the Voting Rights Act extension (S. 1992), the report states:

S. 1992 amends Section 2 of the Voting Rights Act . . . to make clear that proof of discriminatory intent is not required to establish a violation of Section 2 . It thereby restores the legal standards, based on the controlling Supreme Court precedents, which applied to voting discrimination claims prior to the litigation involved in Mobile v. Bolden.

116. See Jones v. City of Lubbock, 640 F.2d 777, 777-79 (5th Cir. 1981) (Goldberg, J., concurring).

117. Id. Discussing the Voting Rights Act extension, Rep. James Sesenbrenner stated:

We are writing into law our understanding of the test in White against Regester. And our understanding is that this looks only to the results of the challenged law . . . But should the Highest Court in the land-or a majority of that Court-conclude that there is a purpose element in White, then the committee has nonetheless drafted a bill that does not incorporate this requirement . . . .

128 CONG. REC. H3841 (daily ed. June 23, 1982). 
tions of Bolden. In Rogers v. Lodge, ${ }^{118}$ the Court declared that "discriminatory intent need not be proven by direct evidence,"119 and found unconstitutional vote dilution based upon a fact situation almost identical to that in Bolden. ${ }^{120}$ The Bolden plurality opinion attempted to disengage federal courts from restructuring local governments in response to equal protection suits, primarily by extending the scope of the intent doctrine. Following Congress' restoration of an intent-free statutory standard, the Gourt in Rogers grudgingly handed down a fact-specific voting rights decision, heavily laden with dicta confirming the role of intent in all equal protection litigation. Ironically, because of the availability of a statutory remedy, the voting rights terrain upon which the intent standard has been nurtured should be the least affected among equal protection claims.

Despite the statutory remedy, Rogers is a paradoxical decision that ex-

118. 102 S. Ct. 3272 (1982).

119. Id. at 3276 .

120. The contrast between the two opinions is highlighted by the comparision in Table 1 of the factors that allowed an inference of intentional discrimination in Rogers but were ruled insufficient in Bolden:

Table 1

\begin{tabular}{|c|c|}
\hline Bolden & Rogers \\
\hline $\begin{array}{l}\text { "It may be that Negro candidates have } \\
\text { been defeated, but that fact alone does not } \\
\text { work a constitutional deprivation." } 446 \\
\text { U.S. at } 73 \text {. }\end{array}$ & $\begin{array}{l}\text { Racial bloc voting plus evidence that all } \\
\text { black candidates have been defeated "bear } \\
\text { heavily on the issue of purposeful } \\
\text { discrimination" and constitute "important } \\
\text { evidence of purposeful exclusion." } 102 \mathrm{~S} \text {. } \\
\text { Ct. at } 3279 \text {. }\end{array}$ \\
\hline $\begin{array}{l}\text { "[E]vidence of discrimination by white } \\
\text { officials is relevant only as the most } \\
\text { tenuous and circumstantial evidence of the } \\
\text { constitutional invalidity of the electoral } \\
\text { system under.which they attained their } \\
\text { offices." Id. at } 74 \text {. }\end{array}$ & $\begin{array}{l}\text { Evidence of official unresponsiveness to } \\
\text { blacks "increases the likelihood that the } \\
\text { political process was not equally open to } \\
\text { blacks." Id. at } 3280 \text {. }\end{array}$ \\
\hline $\begin{array}{l}\text { "[P]ast discrimination cannot, in the } \\
\text { manner of original sin, condemn } \\
\text { governmental action that is not itself } \\
\text { unlawful." Id. }\end{array}$ & $\begin{array}{l}\text { "Evidence of historical discrimination is } \\
\text { relevant to drawing an inference of } \\
\text { purposeful discrimination, particularly in } \\
\text { cases such as this one where the evidence } \\
\text { shows that discriminatory practices were } \\
\text { commonly utilized, that they were } \\
\text { abandoned when enjoined by courts or } \\
\text { made illegal by civil rights legislation, and } \\
\text { that they were replaced by laws and } \\
\text { practices which, though neutral on their } \\
\text { face, serve to maintain the status quo." Id. }\end{array}$ \\
\hline $\begin{array}{l}\text { "[T]he mechanics of the at-large electoral } \\
\text { system . . . are far from proof that the at- } \\
\text { large electoral scheme represents purposeful } \\
\text { discrimination against Negro voters." Id. }\end{array}$ & $\begin{array}{l}\text { Particular factors of at-large systems } \\
\text { "enhance the tendency of multimember } \\
\text { districts to minimize the voting strength of } \\
\text { racial minorities." Id. }\end{array}$ \\
\hline
\end{tabular}


acerbates the confusion in equal protection doctrine. Although professing fidelity to Bolden, Rogers allowed for a diametrically opposite result and liberalized the harsh evidentiary requirements set forth by the Bolden plurality. At the same time, Rogers is the first majority opinion requiring constitutional vote dilution claimants to prove discriminatory purpose in order to establish liability. Rogers reworks White v. Regester ${ }^{\mathbf{1 2 1}}$ into the general framework of intent analysis and strongly suggests that the Fifth Circuit's Zimmer v. McKeithen ${ }^{122}$ factors should be regarded as the central indicia of discriminatory intent, ${ }^{123}$ yet provides no explanation of why these factors were held to be insufficient in Bolden. Nor is there any proof that transforming this evidentiary test in Rogers into the factual basis from which district courts may infer intent aids justiciability.

Without a clearly articulated doctrine governing the scope of intent, ${ }^{124}$ Rogers reduces equal protection claims to particularized findings of fact ${ }^{125}$ capable of tolerating the same discriminatory practices in Mobile, Alabama, found to be unconstitutional in Burke County, Georgia.

\section{Conclusion}

Intent has emerged as the doctrinal linchpin in the Burger Court's reevaluation of the remedies available to equal protection litigants in federal courts. Lurking behind the expanded scope of the intent doctrine is the Court's hostility to relief afforded civil rights plaintiffs. Indeed, by casting the intent requirement over all Fourteenth Amendment litigation, the Court has ominously restricted the capacity of disadvantaged minorities to vindicate constitutional rights ${ }^{128}$ and thereby produced a devastating redefinition of their substantive rights.

The Court's use of intent as the standard for constitutional liability is perfectly consonant with a substantive view of American society as not responsible for the affirmative advancement of blacks and other disadvan-

121. 412 U.S. 755 (1973); see supra note 37.

122. 485 F.2d 1297 (5th Cir. 1973) (en banc), aff'd per curiam on other grounds sub nom. East Carroll Parish School Bd. v. Marshall, 424 U.S. 636 (1976); see supra note 37.

123. 102 S. Ct. at $3277-78$.

124. The Court held the district court's findings of fact not clearly erroneous and relied on the "two-court" rule to not "disturb findings of fact concurred in by two lower courts." $102 \mathrm{~S}$. Ct. at 3279.

125. See Pullman Standard v. Swint, 102 S. Ct. 1781, 1789-91 (1982) (deferential "clearly erroneous" treatment to lower court rulings on intent).

126. This restriction is carried even further in a recent plurality opinion by Justice Rehnquist precluding judicial inquiry into legislative motive. In Michael M. v. Superior Court, 450 U.S. 464 (1981), Justice Rehnquist cites Palmer v. Thompson, 403 U.S. 217 (1971) and United States v. O'Brien, 391 U.S. 367 (1968) to maintain that it is impermissible to strike down statutes "on the basis of an alleged illict motive." 450 U.S. at 472 n.7. Significantly, these cases are cited alongside Washington v. Davis, 426 U.S. 229 (1976) and Village of Arlington Heights v. Metropolitan Hous. Dev. Corp., 429 U.S. 252 (1977). Thus, to establish liability, the litigant would need to prove invidious purpose while eschewing any inquiry into legislative motive. 
taged minorities, a view that ignores the institutional legacies of historical discrimination. If the nature of the violation is defined by its impact on a disadvantaged group, ${ }^{127}$ the appropriate scope of the remedy is equitable relief from the effects of discrimination. But if the violation may be found solely in illicit present motives, relief need not, and indeed may not, try to remedy the institutional perpetuation of historical discrimination. Intent, by taking a perpetrator perspective, ${ }^{128}$ reduces the role of the court to a check on the motives of the state actor, an inherently limited endeavor.

The substantive view underlying the Bolden plurality opinion is succinctly expressed in Justice Stewart's remark that "reconstruction is over."129 Reconstruction assumed an affirmative state obligation to redress the history of discrimination against blacks. During that period blacks voted and held office throughout the former Confederacy. "As a voter the Negro was both hated and cajoled, both intimidated and courted, but he could never be ignored so long as he voted."130

The demise of Reconstruction, the period of "redemption," witnessed the heralding of local self-government as a buttress against the Civil War Amendments and the post-War gains of the freed slaves. Forged in the fire of virulent racism, Jim Crow laws removed blacks from the electorate, shunted them to second class schools and railway cars, and even kept them from the water fountains and telephone booths reserved for whites.

Efforts to dismantle the institutionalized, codified caste-treatment of blacks resurged after World War II, particularly after Brown. The parallels to the post-Civil War period led commentators to term this a second Reconstruction, ${ }^{131}$ and the current. retrenchment on civil rights remedies Redemption II. ${ }^{132}$ Focusing on the subjective intent of the state actor and thereby limiting remedies, the Court has now given constitutional protection to the entrenched practices of local governments that systematically disadvantage blacks in what is still a fundamentally discriminatory soci-

127. See Freeman, Legitimating Racial Discrimination Through Antidiscrimination Law: A Critical Review of Supreme Court Doctrine, 62 MINN. L. REV. 1049, 1052 (1978) (terming this view the victim perspective); Fiss, supra note 9 (discussing group focus in equal protection).

128. Freeman, supra note 127 , at 1052-57.

129. This remark was made in a discussion with Yale law students in the Justice's chambers on Feb. 24, 1981.

130. C.V. WOODWARD, supra note 108 , at 54 .

131. See T. DRAPER, THE REDISCOVERY OF BLACK NATIONALISM 176 (1969) ("In some ways we are living through a second Reconstruction in order to avoid a seccnd Civil War.").

132. Foner, Redemption II, N.Y. Times, Nov. 7, 1981, at 23, col. 2. Among the points of similarity, Professor Foner notes:

With Redemption, efforts to enforce laws promoting racial integration were abandoned. The 15th Amendment, guaranteeing blacks' voting rights, was reduced to a mockery by economic and physical intimidation of black voters and by poll taxes. Blacks' political power was also limited by more subtle means, some of which survive today: gerrymandering districts and the use of at-large elections.

Id. at 23 , col. 4 . 
ety. In effect, the intent doctrine defines the past as a tabula rasa immune from constitutional attack.

Intent may obscure the exact nature of an equal protection violation, but it does not hide the devastating consequences of this doctrine for the vindication of substantive rights. By forcing the victims of entrenched discrimination in this country to establish the motives of institutional actors, either directly as in Bolden or inferentially through heightened evidentiary requirements as in Rogers, the Court has defined the rights of these victims in such a manner as to preclude effective remedies. For many of the victims of racial discrimination, the intent standard comes close to establishing a right for which there can be no remedy. Such a right is no right at all. ${ }^{138}$

133. "To take away all remedy for the enforcement of a right is to take away the right itself." Poindexter v. Greenhow, 114 U.S. 270, 303 (1885). 